\title{
Short-term responses of decomposers to flow restoration in Fossil Creek, Arizona, USA
}

\author{
Jeffrey D. Muehlbauer · Carri J. LeRoy • \\ Jacqueline M. Lovett $\cdot$ Kathleen K. Flaccus • \\ Julie K. Vlieg · Jane C. Marks
}

Received: 10 December 2007 /Revised: 30 July 2008/ Accepted: 1 August 2008/Published online: 26 August 2008

(C) Springer Science+Business Media B.V. 2008

\begin{abstract}
Dam decommissioning projects, although numerous, rarely include complete sets of data before and after restoration for evaluating the ecological consequences of such projects. In this study, we used a before-after control-impact (BACI) design to assess changes in leaf litter decomposition and associated macroinvertebrate and fungal decomposers following dam decommissioning in Fossil Creek, Arizona,
\end{abstract}

Handling editor: S. Stendera

Electronic supplementary material The online version of this article (doi:10.1007/s10750-008-9545-3) contains supplementary material, which is available to authorized users.

J. D. Muehlbauer · J. M. Lovett · J. C. Marks

Department of Biological Sciences, Northern Arizona

University, Flagstaff, AZ 86011, USA

J. D. Muehlbauer ( $\square)$

Curriculum in Ecology, University of North

Carolina-Chapel Hill, 201 Miller Hall, CB 3275, Chapel

Hill, NC 27599, USA

e-mail: jeffreym@unc.edu

\section{J. LeRoy}

The Evergreen State College, Olympia, WA 98505, USA

K. K. Flaccus · J. K. Vlieg

Sinagua High School, Flagstaff Unified School District,

Flagstaff, AZ 86004, USA

J. C. Marks

Merriam Powell Center for Environmental Research, Flagstaff, AZ 86011, USA
USA. Leaf litterbags were deployed in a relatively pristine site above the dam and a highly disturbed site below the dam where over $95 \%$ of the flow was previously diverted for hydropower generation. Leaf litter decomposition was significantly slower below the dam both measurement years (pre- and postrestoration) with no site-year interaction, indicating that decomposition in this stream section was not affected by increased flow. In contrast, both macroinvertebrates and fungi differed significantly above and below the dam prior to restoration but were similar post-restoration, supporting the concept that decomposer communities can quickly rebound following reintroduction of full flow. Our results indicate that some aquatic ecosystem variables can return to a more natural state following ecological restoration activities such as water flow restoration.

Keywords Dam decommissioning ·

Leaf litter decomposition - Flow restoration .

Diversion dam · Fungi · Macroinvertebrates

\section{Introduction}

Dam decommissioning, that is, the termination of some function of a dam, either by altering operation or by dam removal, has become popular in attempting to reverse ecosystem degradation caused by dams (Hart et al., 2002; Stanley \& Doyle, 2003; Marks, 
2007; Doyle et al., 2008). Many dam effects, such as sediment retention, water flow reduction, and alterations in habitat structure are thought to detrimentally affect ecosystems by altering biotic communities, ecosystem services, and ecological processes (e.g., Ward \& Stanford, 1983; Bednarek, 2001). Dam decommissionings offer the potential to reverse some of these disturbances and return streams to more natural states. However, the majority of dam decommissionings, like most stream restoration projects, lack pre-restoration data and clearly defined goals, making quantitative comparisons before and after restoration difficult (Hart et al., 2002; Doyle et al., 2003a; Palmer et al., 2005; Bernhardt et al., 2005).

Biotic recovery in response to stream restoration can be rapid, especially when the physical and chemical condition of the stream has not been severely disturbed (Niemi et al., 1990; Gore et al., 1990). Positive impacts of dam decommissionings have been observed or are predicted by alleviating the disturbance effects caused by damming. Restoration goals of dam removals often focus on removing the impoundment and re-creating lotic conditions above the dam but may also emphasize restoring downstream habitat and reconnecting habitats above and below the dam (Hart et al., 2002 and references therein; Stanley et al., 2002; Marks, 2007). Other positive, long-term geomorphic responses are possible based on models, although significant uncertainty remains (Doyle et al., 2002; Doyle et al., 2003b).

Problematic side effects of dam decommissionings and removals include the downstream release of contaminated or nutrient-laden sediment, channelization and channel scour, and extirpation of lenticadapted organisms upstream in the impounded reservoir (Bednarek, 2001; Stanley \& Doyle, 2003; Sethi et al., 2004). Although dams often alter both upstream and downstream food webs, particularly with respect to the macroinvertebrate community (Power et al., 1996; Al-Lami et al., 1998; Cortes et al., 1998; Stanley et al., 2002), one study found that litter decomposition, macroinvertebrate biomass, biological oxygen demand, and nutrient concentrations were not different in sites above and below a dam, indicating that negative effects of dams may not be universal (Casas et al., 2000). Consequently, comparisons before and after restoration are important in establishing whether restoration projects such as dam decommissionings are successful in improving the overall condition of an ecosystem (Yount \& Niemi, 1990).

Variability in dams and ecosystems also limits comparative ability among restoration efforts. Despite a large body of research related to aquatic discontinuity effects (e.g., Ward \& Stanford, 1983), dam effects vary widely depending on the size and functional characteristics of the dam, such as water retention and hydraulic head (Poff \& Hart, 2002). The majority of available decommissioning literature has also come from small dam removal studies in the US Midwest (e.g., Stanley et al., 2002; Doyle et al., 2005; Cheng \& Granata, 2007), which differ in climate, species composition, and likely recovery time in comparison to other ecoregions, such as the arid ecosystems of the US Southwest (Hughes et al., 1990). Additionally, studies concerned with the downstream effects of restoration rather than focusing on upstream changes in the former reservoir tend to have emphasized sediment fining (Cheng \& Granata, 2007) and varying degrees and timescales of nutrient increases (Bushaw-Newton et al., 2002; Ahearn \& Dahlgren, 2005; Riggsbee et al. 2007), but these changes are unlikely to occur in dam decommissionings where the dam stays intact. Although these studies provide valuable information on the effects of dam removals (removal of structure, reconnection of upstream and downstream sites, release of sediments, nutrient pulses, and more), it remains difficult to evaluate the restoration potential of site-specific attributes of a dam decommissioning, particularly when the dam is not removed.

The dam decommissioning in Fossil Creek, Arizona, USA, presented a unique opportunity to study flow restoration decoupled from other restoration effects, particularly sediment release, because the decommissioning is being conducted in stages over a four-year period rather than initiating dam removal and flow restoration simultaneously. In 2005, water flow that was previously diverted from the stream via a flume at the dam was restored when the hydropower facility was decommissioned, but the dam itself will not be removed until 2009. Flow was restored by keeping the water diversion in place at the dam but removing the flume structure just below it, allowing water to be diverted around the dam and be reintroduced just below the dam at full flow (Fig. 1, Online Supplementary Figure). 
In this work, we quantify some of the short-term effects of returning full flow below Fossil Creek Dam. Leaf litter decomposition, macroinvertebrate community attributes, fungal biomass, and water quality and chemistry were compared before and after restoration above and below the dam to test the following hypotheses regarding short-term ecological responses: (1) The water diversion would have reduced leaf litter decomposition immediately below the dam and restoration of flow would reverse this pattern, resulting in similar decomposition rates at both sites. (2) Decomposition of different leaf species would vary between sites prior to decommissioning and would not respond uniformly to restoration. This hypothesis was based in part on another study in the area that found significant differences in leaf decomposition rates between local species depending primarily on litter quality (LeRoy \& Marks, 2006) and our assumption that the strength of speciesspecific changes in leaf decomposition due to differences or alterations in water flow would be influenced in part by the quality of the litter. (3) Fungal biomass and macroinvertebrate abundance and diversity would be depressed below the dam but would recover following restoration. (4) Macroinvertebrate community structure would differ between sites prerestoration, but would be similar after restoration. We expected to observe these changes or the initial trajectories of such changes within six months after restoration.

\section{Materials and methods}

\section{Site descriptions}

Fossil Creek is a spring-fed stream that begins 2,212 $\mathrm{m}$ above sea level and ends at the Verde River $777 \mathrm{~m}$ above sea level approximately $23 \mathrm{~km}$ downstream. The five primary geothermal springs at its origin empty at a rate of $1,218 \mathrm{l} / \mathrm{s}$ at $21^{\circ} \mathrm{C}$. Less than $1 \mathrm{~km}$ below the springs a $10-\mathrm{m}$ hydropower dam diverted water to two hydropower plants for nearly one hundred years, reducing base flow directly below the dam by more than $95 \%$, to 5.6 1/s (Malusa et al., 2003). Large vegetation consists of typical regional riparian flora, including Fremont cottonwood (Populus fremontii S. Wats.) and Arizona alder (Alnus oblongifolia Torr.), which were used in this research.
The two study sites used for this project were approximately $400 \mathrm{~m}$ above and $100 \mathrm{~m}$ below the Fossil Creek Dam. Both sites were located in stream sections characterized as small pools with cobble substrate, approximately $1.0 \mathrm{~m}$ in depth, $15-20 \mathrm{~m}$ in width, and $50 \mathrm{~m}$ in length post-restoration. Before flow restoration, the below-dam site was shallower and narrower, approximately $0.5 \mathrm{~m}$ in depth and $10 \mathrm{~m}$ in width, whereas the dimensions of the abovedam site were similar pre- and post-restoration. Sites were chosen to be close to the dam while remaining outside the small, artificial reservoir above the dam and the deep pool below the dam (Monroe, 2002; Fig. 1). The above-dam site represented a relatively intact "control" site, while the below-dam site was representative of much of the disturbed stream reach. Study sites were sampled during the winters of 2003 (18 months before flow restoration) and 2005 (six months after restoration). The 2003 study was initially carried out with the intent of being six to twelve months prior to restoration, but delays in dam decommissioning increased the temporal separation between this study and the actual flow restoration date. Because this study was intended to observe short-term changes following flow restoration, the 2005 study was conducted six, rather than eighteen, months after restoration.

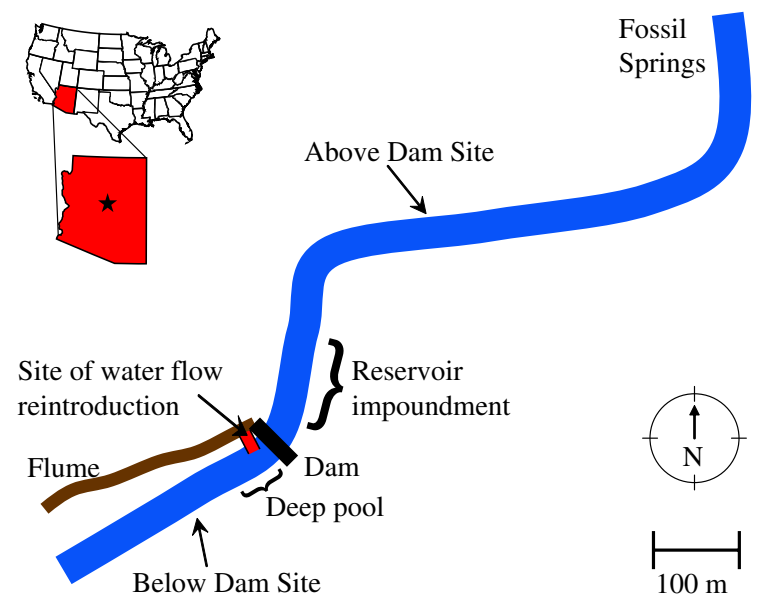

Fig. 1 Schematic showing study sites in Fossil Creek relative to the location of the dam and pools. Following dam decommissioning, water formerly diverted downstream via the flume was reintroduced at full flow just below the dam 
Water quality and chemistry

Temperature, dissolved oxygen (DO), DO percent saturation, $\mathrm{pH}$, salinity, total dissolved solids (TdS), and specific conductivity ( $\mathrm{SpC}$ ) were measured using a minisonde probe (Hydrolab-Hach Corporation, Loveland, Colorado, USA) at both sites during the first litterbag removal (day 10) both years. Several measurements were taken at random points across the channel width, and these were averaged together for each site. Three replicate $250-\mathrm{ml}$ water samples were also taken from random points across the channel width at both sites using acid-washed, HDPE bottles and were kept on ice during transport then frozen until nutrient analysis. These samples were analyzed for $\mathrm{PO}_{4}{ }^{3-}, \mathrm{NO}_{3}{ }^{-}$, and $\mathrm{NH}_{4}{ }^{+}$concentrations using a QuikChem FIA + 8000 automated spectrophotometer system (Lachat-Hach Corporation, Loveland, Colorado, USA). A sample from each replicate was analyzed to ensure that any outlier samples containing possible contamination of a single bottle or artificially high concentrations of nutrients from any microsites would not be used for further analysis.

\section{Leaf litter decomposition}

Populus fremontii and Alnus oblongifolia leaves were collected from nearby Beaver Creek by hanging tarps under trees to catch leaves during natural abscission in fall 2002 and stored indoors in sealed boxes at room temperature until used in 2003 or 2005. The litter quality of these species was similar in terms of percent phosphorous and condensed tannins, but $A$. oblongifolia had significantly higher percent nitrogen concentration based on a previous study using leaves from the same source (LeRoy \& Marks, 2006). Leaves were separated by species and laid flat in $6.4 \mathrm{~mm}$ mesh litterbags in $4.0 \mathrm{~g}$ quantities. Four litterbag treatments were used per measurement year: $P$. fremontii above and below the dam and $A$. oblongifolia above and below the dam. Litterbags were randomly anchored in the stream over a spatial extent of approximately $20 \mathrm{~m}$ of stream length and the middle $10 \mathrm{~m}$ of stream width at the above- or below-dam sites in replicates of eight for 10 or 75 days. To avoid temporal bias in decomposition rates between sites all litterbags (above and below dam) were submerged in the stream on the same day and were therefore removed from both sites on the same days (e.g., the day 10 removal represented the same calendar date for both sites). Handling losses were estimated from mass loss in control litterbags that were carried to and from Fossil Creek with the other litterbags but never submerged in the stream.

On removal dates the leaf litter remaining in litterbags was washed and filtered through $250-\mu \mathrm{m}$ nets to remove sediment. The retained macroinvertebrates were preserved in $70 \%$ ethanol for further processing. Two sets of five 11-mm leaf punches were taken per litterbag from a stack of five leaves for fungal biomass determination. The remaining litter was dried at $70^{\circ} \mathrm{C}$ for $72 \mathrm{~h}$ then ground using a Wiley mill (Thomas Scientific, Swedesboro, New Jersey, USA) and combusted at $500^{\circ} \mathrm{C}$ in a muffle furnace (Barnstead International, Dubuque, Iowa, USA) for $1 \mathrm{~h}$ to determine ash-free dry mass (AFDM) values. Natural log equations were created for AFDM values to determine experimental leaf decomposition rates (k) from 10 to 75 days in-stream. These rates were compared using an equality of slopes test in SAS (Version 8.01, SAS Institute, Inc., Cary, North Carolina, USA, 2000), which allowed decomposition rates between species and sites to be compared within and between measurement years (Jenny et al., 1949; Olson, 1963; Petersen \& Cummins, 1974; Webster \& Benfield, 1986).

\section{Fungal biomass}

Fungal biomass analysis was done using only leaf punch sets taken from litterbags removed at day 10 because leaves from the day 75 removal were too advanced in decomposition to allow taking adequate leaf punches. From the two sets of leaf punches taken during processing of the day 10 litterbags, one set of punches was preserved in methanol (99.99\% HPLCgrade) and the other set was dried, ground, and combusted in the same manner as the rest of the leaf litter. Ergosterol concentrations were determined from the sets of leaf punches preserved in methanol. Because this sterol is largely unique to fungus, its concentration in aquatic systems is directly related to the abundance of hyphomycetes (Newell, 1992), and multiplying by a constant then provides a quantitative measure of fungal biomass (Gessner \& Chauvet, 1993). The assay for ergosterol, high-performance liquid chromatography (HPLC) parameters, and mathematical conversion to $\mathrm{mg}$ fungus was done 
according to the methods of Suberkropp (2001), with the exception that the residue dissolved in $1 \mathrm{ml}$ of methanol was filtered using 13-mm Acrodisc filters with a $0.2-\mu \mathrm{m}$ PTFE membrane. Five standards of known ergosterol concentration $(1,2.5,5,10$, and $25 \mu \mathrm{g} \mathrm{ml}^{-1}$ ) were run every time the machine was started, and a randomly chosen standard was run after every 10-12 samples to verify consistent HPLC performance. Obtained fungal values were divided by AFDM values from the other set of leaf punches to determine $\mathrm{mg}$ fungal biomass per g AFDM. Because site and year were the major factors of interest, leaf species was not used as a factor in the fungal biomass analysis.

\section{Aquatic macroinvertebrates}

Macroinvertebrates associated with the leaf litter were collected during day 10 removal. Most of the macroinvertebrates retained following leaf litter washing were identified to the genus level using dichotomous keys (e.g., Merritt \& Cummins, 1996; Wiggins, 1996; Thorpe \& Covich, 2001). Due to difficulty in differentiating aquatic Diptera and Coleoptera, macroinvertebrates in these orders were identified to the family level. Non-metric multidimensional scaling (NMDS) with a Bray-Curtis distance measure provided a visual representation of the macroinvertebrate community structure (PC-ORD Version 4.02, MJM Software, Gleneden Beach, Oregon, USA, 1999). Macroinvertebrate community differences between harvest dates, sites, measurement years, and site-measurement year combinations were analyzed using a multi-response permutation procedure (MRPP; McCune \& Grace, 2002). Community attributes including species evenness, richness, Shannon's diversity index $\left(\mathrm{H}^{\prime}\right)$, and Simpson's diversity index $\left(\mathrm{D}^{\prime}\right)$ were also compared using the BACI analysis method described in the next section.

\section{Statistical analyses and BACI design}

JMP-IN software was used for the majority of statistical data analyses (Academic version 5.1.2, SAS Institute, Inc., Cary, North Carolina, USA, 1989-2001). A type I error rate $(\alpha)$ of 0.05 was used for all relevant analyses.

To test for effects of restoration on water quality and chemistry, leaf litter decomposition, fungal biomass, and macroinvertebrate community attributes we used a before-after control-impact (BACI) design, where "before-after" represented the pre- vs. postrestoration measurements, and "control-impact" represented the above- vs. below-dam sites (Green, 1979; Smith, 2002). In this analysis significant main effects (site and year) indicate that either the sites are different or that there is a temporal effect. A significant interaction term indicates that differences between sites above and below the dam differed before and after restoration. The interaction term indicates whether restoration changed the relationship between sites. Whereas most assessments employing BACI designs test for differences among treatment and control sites following disturbance, we were testing if our sites became more similar after restoration.

BACI designs are intended to reduce the statistical problems and logical fallacies associated with pseudoreplication (Hurlburt, 1984) that are common in freshwater ecology and restoration studies. Two-site, single-measure BACI designs like the one used in this study lack the power to infer that observed "before" to "after" changes in the "impact" site are due to the disturbance or restoration being studied and not in part to some other factor or combination of factors (Underwood, 1992; Downes et al., 2002). Significant interaction terms indicate that differences between treatments coincided with restoration but could be due to other factors. The uniqueness of Fossil Creek (as a perennial geothermal, travertine stream in an arid region) and the location of the dam so close to the headwaters eliminated any possibility of designating a similar reference stream and prohibited us from creating additional "control" sites above the dam. Our ability to replicate temporally was also limited because the final decision to decommission the facility was made within a year of the actual decommissioning, preventing collection of multiple years of decomposition data prior to restoration. Although this design limits our ability to make statistical inference these constraints are typical of restoration projects where scientists often need to make tradeoffs between ideal experimental designs and the need for assessments of management actions (Bernhardt et al., 2005; e.g., Pollard \& Reed, 2004; Sethi et al., 2004). We also opted not to include multiple downstream sites because lower reaches of the stream were treated with antimycin A to remove 
exotic fish. The sites in this experiment are upstream of this manipulation (Weedman et al., 2005; Marks, 2007). Despite its limitations, such a BACI design is recommended where disturbances or restorations cannot be replicated across multiple sites and where additional control sites are not available (Osenberg \& Schmitt, 1996), which is why the design was chosen for this study.

\section{Results}

Water quality and chemistry

The interaction effect of site and year was significant for temperature $\left({ }^{\circ} \mathrm{C}\right), \mathrm{SpC}(\mu \mathrm{S} / \mathrm{cm}), \mathrm{TdS}(\mathrm{g} / \mathrm{l})$, and $\mathrm{pH}$, but not for $\mathrm{DO}, \mathrm{NO}_{3}{ }^{-}$, or $\mathrm{PO}_{4}{ }^{3-}$ (Table 1). Because measured values for $\mathrm{NH}_{4}{ }^{+}$were all near or below the detection limit, no statistical analyses were run for the $\mathrm{NH}_{4}{ }^{+}$data. In the case of temperature, water below the dam warmed by $9^{\circ} \mathrm{C}$, from $11.6^{\circ} \mathrm{C}$ in 2003 to $20.6^{\circ} \mathrm{C}$ in 2005 , while the temperature above the dam remained at approximately $21.1^{\circ} \mathrm{C}$. TdS and SpC concentrations below the dam in 2005 also increased relative to their concentrations in 2003 and in proportion to the above-dam values. The values for $\mathrm{pH}$ above and below the dam in 2005 both decreased relative to 2003 values, and $\mathrm{pH}$ remained lower above in comparison to below the dam. As in 2003, DO concentrations below the dam were higher than above the dam in 2005. $\mathrm{NO}_{3}{ }^{-}$concentrations increased and $\mathrm{PO}_{4}{ }^{3-}$ concentrations decreased both above and below the dam in 2005 relative to 2003, although these changes were not significant.

\section{Leaf litter decomposition}

Leaf litter decomposition was slower below the dam both before and after restoration as indicated by a significant site effect (Fig. 2). There was no significant year effect nor was there a significant interaction between site and year, indicating that decomposition rates were relatively constant through time both above and below the dam. There were also no significant differences in decomposition between any leaf species/site/measurement year groupings of factors except in A. oblongifolia litterbags located above and below the dam in $2003(F=5.69$, $P=0.0181)$.

\section{Fungal biomass}

Fungal biomass was approximately 10 times lower for litterbags located below the dam when compared to above-dam values in 2003 (Fig. 2). Following dam decommissioning, fungal biomass at the two sites was nearly equal, and both values were approximately $30 \%$ greater than the average fungal biomass on leaves located above the dam in 2003. The interaction of site with year was significant $(F=8.45, P=0.0053)$, indicating that fungal biomass differed at the sites before but not after restoration.

Table 1 Water quality and chemistry values from above- and below-dam sites taken during the first leaf removal date in 2003 (predecommissioning) and 2005 (post-decommissioning)

\begin{tabular}{|c|c|c|c|c|c|c|}
\hline \multirow[t]{2}{*}{ Parameter } & \multicolumn{2}{|l|}{2003} & \multicolumn{2}{|l|}{2005} & \multicolumn{2}{|c|}{ BACI interaction } \\
\hline & Above dam & Below dam & Above dam & Below dam & $F$ & $P$ \\
\hline Flow (1/s) & 1,218 & 5.6 & 1,218 & 1,218 & $\mathrm{n} / \mathrm{a}$ & $\mathrm{n} / \mathrm{a}$ \\
\hline Temperature $\left({ }^{\circ} \mathrm{C}\right)$ & $21.13 \pm 0.015$ & $11.61 \pm 0.051$ & $21.14 \pm 0.002$ & $20.58 \pm 0.040$ & 6011.1 & $<0.0001^{*}$ \\
\hline $\mathrm{pH}$ & $7.43 \pm 0.010$ & $8.08 \pm 0.006$ & $6.58 \pm 0.003$ & $6.85 \pm 0.015$ & 123.9709 & $<0.0001 *$ \\
\hline D.O. $(\mathrm{mg} / \mathrm{l})$ & $7.16 \pm 0.147$ & $7.69 \pm 0.105$ & $6.51 \pm 0.085$ & $7.43 \pm 0.033$ & 1.28 & 0.2909 \\
\hline Total dissolved solids ( $\mathrm{g} / \mathrm{l}$ ) & $0.45 \pm 0.002$ & $0.40 \pm 0.000$ & $0.48 \pm 0.000$ & $0.47 \pm 0.000$ & 46.37 & $0.0001 *$ \\
\hline Specific conductivity $(\mu \mathrm{S} / \mathrm{cm})$ & $704.10 \pm 0.033$ & $629.43 \pm 0.195$ & $752.97 \pm 0.069$ & $738.2 \pm 0.100$ & 22117.87 & $<.0001 *$ \\
\hline Ammonium $\left(\mathrm{NH}_{4}{ }^{+} \mathrm{mg} / \mathrm{l}\right)$ & $<0.034$ & $0.064 \pm 0.0089$ & $<0.034$ & $<0.034$ & $\mathrm{n} / \mathrm{a}$ & $\mathrm{n} / \mathrm{a}$ \\
\hline Nitrate $\left(\mathrm{NO}_{3}{ }^{-} \mathrm{mg} / \mathrm{l}\right)$ & $0.46 \pm 0.030$ & $0.40 \pm 0.020$ & $0.59 \pm 0.036$ & $0.60 \pm 0.005$ & 1.58 & 0.238 \\
\hline Phosphate $\left(\mathrm{PO}_{4}{ }^{3-} \mathrm{mg} / \mathrm{l}\right)$ & $0.08 \pm 0.01$ & $0.06 \pm 0.007$ & $0.03 \pm 0.004$ & $0.03 \pm 0.004$ & 2.6200 & 0.1369 \\
\hline
\end{tabular}

Error values are \pm 1 SE. Significant BACI interactions at the $5 \% \propto$ level are depicted with asterisks $(*)$ 

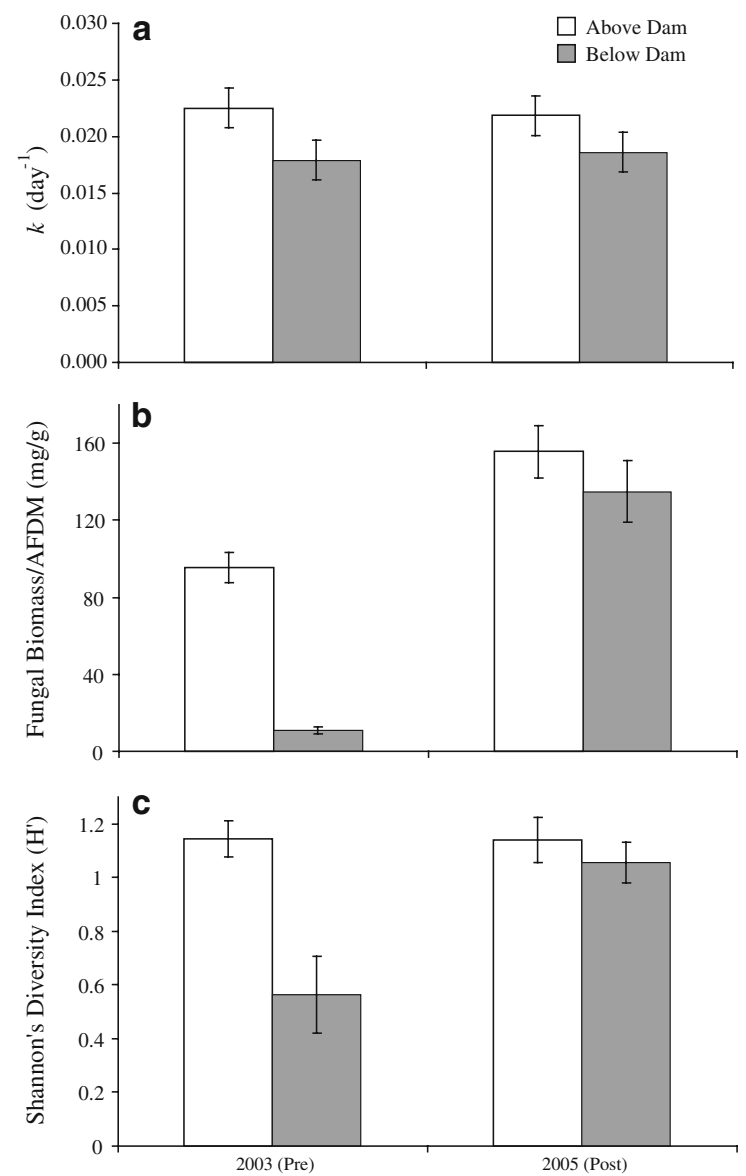

Fig. 2 (a) Leaf litter decomposition rate constants $(k)$ for Populus fremontii and Alnus oblongifolia above and below Fossil Creek Dam pre- (2003) and post- (2005) decommissioning (BACI $F=1.38, \quad P=0.24 ; \quad$ CI $F=43.66$, $P<0.0001$ where "BACI" refers to the site with year interaction term and "CI" refers to a site effect). Because there were no significant differences between leaf species within sites or years, they have been grouped together for simplicity. (b) Aquatic fungal biomass per AFDM of leaf mass remaining after harvest day 10 (BACI $F=8.45, P=0.0053$ ). (c) Shannon's diversity index $\left(\mathrm{H}^{\prime}\right)$ values for macroinvertebrates associated with litterbags (BACI $F=6.39$, $P=0.0142$ ). Error bars represent $\pm 1 \mathrm{SE}$

\section{Aquatic macroinvertebrates}

The macroinvertebrate community differed significantly above versus below the dam prior to restoration but began to converge following restoration (Fig. 3). The MRPP for the site with year interaction of macroinvertebrate community structure was significant $(A=0.1118, \quad P<0.001$, stress $=17.66$, instability $=0.0005)$. This analysis

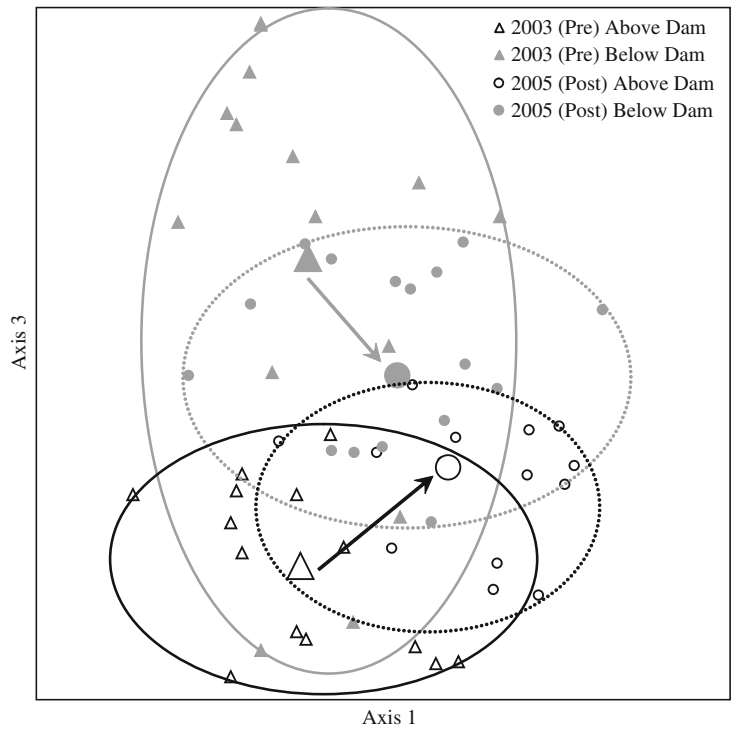

Fig. 3 NMDS ordination shows significantly different macroinvertebrate communities above versus below Fossil Creek Dam pre- (2003) and post- (2005) decommissioning (MRPP statistic $A=0.1415, P<0.0001$, stress $=17.66$, instability $=0.0005)$. Large icons are centroids representing the mean value of each group of data points and so may not fall directly in the center of the ellipses, the shapes of which tend to be skewed by a few, outer points. Arrows represent changes in centroid locations at each site from 2003 to 2005

indicated little difference in macroinvertebrate community structure in the above-dam system between measurement years. The locations on the NMDS ordination of each litterbag from this site were grouped closely to one another, with the ellipses roughly the same size and centroid locations exhibiting a small community shift indicative of interannual variation. The below-dam community, however, changed significantly following restoration and began to resemble the above-dam species structure. Variation among replicates below the dam in 2003 was the highest of the four site-year combinations; that is, the grouping of these litterbags was relatively more dispersed in the NMDS ordination. Macroinvertebrate assemblages on litterbags below the dam post-restoration (in 2005) exhibited a greater degree of homogeneity than in 2003; however, the ordination of macroinvertebrates collected below the dam in 2005 was still more dispersed than the above-dam community. This suggests some time-lag between restoration and complete recovery to above-dam conditions, and emphasizes the need for long-term monitoring in such research. 
Site with year interactions for abundance and richness were not significant at the $5 \%$ level $(F=3.90, P=0.0533$ for abundance and $F=3.85$, $P=0.0546$ for richness), but both showed a strong trend of smaller differences between sites in 2005 relative to 2003. Abundance and richness were higher above than below the dam in 2003 and remained so in 2005, but the difference was less pronounced.

There was a significant site with year interaction for Shannon's diversity index ( $\mathrm{H}^{\prime}$; Fig. 2), indicating that diversity was lower below relative to above the dam prior to restoration, but was similar at both sites after flow was restored. A similar trend was noted for Simpson's diversity index, although it was not significant $\left(\mathrm{D}^{\prime} ; F=0.87, P=0.3572\right)$.

\section{Discussion}

Following flow restoration, Fossil Creek below the dam appears to be returning to a state similar to the above-dam system. Fungal biomass equalized between sites six months following restoration and macroinvertebrate communities on leaf packs below the dam more closely resemble the above-dam community. Leaf litter decomposition does not seem to have been affected by a change in water flow, suggesting that flow is not the driving force behind decomposition in Fossil Creek.

Fungal biomass as a function of leaf litter AFDM was significantly lower below the dam than above the dam prior to restoration but was nearly equal after restoration, indicating that fungi may be more capable of a rapid response to aquatic restoration activities than macroinvertebrates. Fungi likely responded positively to the increases in temperature and flow (Sanders \& Webster, 1980, cited in Chauvet \& Suberkropp, 1998) although given this experimental design it is impossible to separate the independent effects of these variables. The increase in fungal biomass in the above-dam control site in 2005 compared to 2003 is likely attributable to meteorological phenomena rather than to a change in the above-dam system; the winter of 2005 was abnormally sunny, dry, and warm, whereas 2003 was very snowy and colder (J. D. Muehlbauer, personal observation).

The reduced macroinvertebrate diversity and altered community structure differences that we observed between the disturbed and free-flowing sites are consistent with those predicted by the Serial Discontinuity Concept, where a dam in a low-order stream should reduce diversity immediately below it (Ward \& Stanford, 1983). Although diversity, richness, and abundance increased below the dam, they are still slightly lower than above the dam. This could be due to a time lag or because other unstudied biological or physical/environmental aspects of the site are less conducive to macroinvertebrates. The pre-restoration differences between sites are also similar to a water diversion/dam system in Portugal where a large degree of community variation was found downstream of the dam and water impoundment (Cortes et al., 1998). Dams however do not always reduce the diversity and density of macroinvertebrate communities (Casas et al., 2000) and can even increase densities (Al-Lami et al., 1998). Habitats below dams can be hospitable for macroinvertebrates if nutrient concentrations are elevated below the dam (Casas et al., 2000) or current velocity and substrate availability are more favorable (AlLami et al., 1998), although this was not the case in Fossil Creek. The rapid response of macroinvertebrates to restoration is similar to that observed in a dam removal in Wisconsin where macroinvertebrates above a dam quickly shifted from a lentic to lotic community (Stanley et al., 2002). In another Wisconsin dam removal study, the greatest changes in the macroinvertebrate community occurred nearest the former dam site (Pollard \& Reed, 2004), which also corroborates the results of this research. The macroinvertebrate communities that we observed in litterbags support a comprehensive four-year study (pre- and post-decommissioning) on macroinvertebrate assemblages on multiple substrates and locations in Fossil Creek showing that the macroinvertebrate community directly below the dam is shifting towards a more pristine, above-dam state (Dinger, 2006).

The lack of response in decomposition below the dam is surprising given significant differences in macroinvertebrates, fungi, water flow, and temperature, which can be contributors to leaf litter decomposition (Casas et al., 1994; Baldy \& Gessner, 1997; Webster \& Benfield, 1986). These results are in agreement with a study on a similar-order stream diverted by a headwater dam in Spain that found no difference in decomposition rates above versus 
below the dam during dam operation, although the macroinvertebrate community did not change over the course of that study (Casas et al., 2000). Given the intense regional drought in 2005, these findings are inconsistent with another study that suggests water diversions and drought both cause a significant decrease in decomposition (Pinna et al., 2003); possibly suggesting that decomposition should have decreased above the dam while potentially increasing below-dam from 2003 to 2005. Fossil Creek however is spring-fed and base flow is less sensitive to inter-annual differences in precipitation. Increased travertine deposition on the litterbags below the dam post-restoration (J. D. Muehlbauer, personal observation) may have decreased decomposition rates. This is in contrast to another study in Fossil Creek that predicted increases in leaf litter decomposition with more travertine (Carter \& Marks, 2007). However, that study emphasized the effect of leaf adhesion to travertine dams, which would both expose and hold leaves in place for rapid microbial and invertebrate decomposition. In this study, leaves at the downstream site became completely encased in travertine, potentially reducing leaf-surface availability to macroinvertebrates (Casas et al., 1994) or minimizing fragmentation (Casas \& Gessner, 1999; LeRoy \& Marks, 2006). This could have offset any increases in decomposition rates caused by flow restoration.

Contrary to our prediction, leaf litter decomposition rates for the two species ( $P$. fremontii and $A$. oblongifolia) did not differ as they have in previous studies (LeRoy \& Marks, 2006). It is possible that the timing of litterbag removal from the stream (at 10 and 75 days) influenced these results and may have masked decomposition differences between sites as well. At ten days, it is possible that a substantial amount of time had not passed to allow decomposition to vary tremendously, while at 75 days it is feasible that decomposition had reached an asymptote and had slowed to almost zero. Decomposition rate comparisons among treatments were unbiased because leaves were removed from both sites on the same dates, but having additional removal dates near these times and in the middle of the range likely would have been helpful in more confidently presenting these results. In fact, the experiment had included a plan for an intermediate removal date that had to be cancelled due to inclement weather.

\section{Conclusion}

The two-site, single-measure BACI design limits our power to infer that the changes and site with year interactions observed are due to restoration alone and not to some combination of factors. Nevertheless, these data indicate that aspects of stream ecosystems such as macroinvertebrate and fungal communities can be reversed quickly when major components of the disturbance are alleviated. These results are consistent with a long-term study showing that macroinvertebrates in Fossil Creek rebounded very quickly from treatment with antimycin $\mathrm{A}$, where the macroinvertebrate assemblage was decimated but within 6 months most species returned to pre-disturbance levels (Dinger, 2006). Water was diverted from Fossil Creek for almost a century, yet two important guilds of decomposers seem to have rebounded within 6 months of flow restoration. Continual monitoring of these sites and future studies following the pending removal of the dam, slated for 2009, will be valuable in assessing dam effects not solely accounted for by water flow restoration. Such effects, particularly the rapid release of sediments deposited above the dam, are thought to have a major influence on ecosystems below dams (Stanley \& Doyle, 2003). Of course, given the extreme variation in streams and dams and the ecosystems in which they are found (Poff \& Hart, 2002; Riggsbee et al., 2007), more experiments are necessary not only in Fossil Creek, but also in other systems. This would allow policy makers to understand the ecological implications of dam decommissionings and removals on a more practical regional and dam-size scale (Hughes et al., 1990). Such knowledge would also benefit the many, similar restoration projects already in action or in the planning stages (Heinz Center, 2002; Bernhardt et al., 2005). Responses to dam decommissioning are likely to depend on the type and magnitude of disturbance created by the dam (Poff \& Hart, 2002) and the ability for restoration to mitigate specific disturbances. Here, we show that mitigating one aspect of the disturbance, flow, has the potential to quickly reverse some of the differences between pristine and disturbed sites.

Acknowledgments This project was funded by the Ecological Restoration Institute (ERI) at Northern Arizona University (NAU), the National Science Foundation's Research Experience for Teachers (RET) program as part of NSF grant \#0130487, and NSF grant \#DEB-0543612. We 
would like to thank Sinagua High School for allowing teachers J. Vlieg and K. Flaccus and students J. Lovett, P. Norman, K. Plichta, J. Plichta, M. Patrick, I. Delaney, and S. Bennett to participate in research activities during and after school. We appreciate the cooperation of management agencies and corporations associated with Fossil Creek, including the Arizona Public Service, Coconino and Tonto National Forests, and the U.S. Fish and Wildlife Service. We would like to thank the Marks and Hungate research teams, and the Ecological Restoration Institute at Northern Arizona University for their assistance. We thank F. Lu, L. Brewington, B. Miller, and two anonymous reviewers for their insightful comments on earlier drafts of this paper.

\section{References}

Ahearn, D. S. \& R. A. Dahlgren, 2005. Sediment and nutrient dynamics following a low-head dam removal at Murphy Creek, California. Limnology and Oceanography 50: 1752-1762.

Al-Lami, A. A., H. J. Jaweir \& M. R. Nashaat, 1998. Benthic invertebrates community of the river Euphrates upstream and downstream sectors of Al-Qadisia dam, Iraq. Regulated Rivers: Research and Management 14: 383-390.

Baldy, V. \& M. O. Gessner, 1997. Towards a budget of leaf litter decomposition in a first-order woodland stream. Comptes Rendues de l'Académie des Sciences Paris, Série III, Sciences de la vie/Life Sciences 320: 747-758.

Bednarek, A., 2001. Undamming rivers: a review of the ecological impacts of dam removal. Environmental Management 27: 803-814.

Bernhardt, E. S., M. A. Palmer, J. D. Allan, G. Alexander, K. Barnas, S. Brooks, J. Carr, S. Clayton, C. Dahm, J. Follstad-Shah, D. Galat, S. Gloss, P. Goodwin, D. Hart, B. Hassett, R. Jenkinson, S. Katz, G. M. Kondolf, P. S. Lake, R. Lave, J. L. Meyer, T. K. O’Donnell, L. Pagano, B. Powell \& E. Sudduth, 2005. Synthesizing U.S. river restoration efforts. Science 308: 636-637.

Bushaw-Newton, K. L., D. D. Hart, J. E. Pizzuto, J. R. Thomson, J. Egan, J. T. Ashley, T. E. Johnson, R. J. Horwitz, M. Keeley, J. Lawrence, D. Charles, C. Gatenby, D. A. Kreeger, T. Nightengale, R. L. Thomas \& D. J. Velinsky, 2002. An integrative approach towards understanding ecological responses to dam removal: the Manatawny Creek study. Journal of the American Water Resources Association 38: 1581-1599.

Carter, C. D. \& J. C. Marks, 2007. Influences of travertine dam formation on leaf litter decomposition and algal accrual. Hydrobiologia 575: 329-341.

Casas, J. J. \& M. O. Gessner, 1999. Leaf litter breakdown in a Mediterranean stream characterized by travertine precipitation. Freshwater Biology 41: 781-793.

Casas, J. J., J. Picazo \& M. L. Carcelen, 1994. Leaf packs breakdown in a karstic Mediterranean stream. Verhandlungen der Internationalen Vereinigung für Limnologie 25: 1739-1744.

Casas, J. J., C. Zamora-Muñoz, F. Archila \& J. Alba-Tercedor, 2000. The effect of a headwater dam on the use of leaf bags by invertebrate communities. Regulated Rivers: Research and Management 16: 577-591.

Chauvet, E. \& K. Suberkropp, 1998. Temperature and sporulation of aquatic hyphomycetes. Applied and Environmental Microbiology 64: 1522-1525.

Cheng, F. \& T. Granata, 2007. Sediment transport and channel adjustment associated with dam removal: Field observations. Water Resources Research 43: WO3444.

Cortes, R. M. V., M. T. Ferreira, S. V. Oliveria \& F. Godinho, 1998. Contrasting impact of small dams on the macroinvertebrates of two Iberian mountain rivers. Hydrobiologia 389: 51-61.

Dinger, E. C., 2006. Aquatic conservation in southwest karstic ecosystems. PhD Thesis, Northern Arizona University, Flagstaff.

Downes, B. J., L. A. Barmuta, P. G. Fairweather, D. P. Faith, M. J. Keough, P. S. Lake, B. D. Mapstone \& G. P. Quinn, 2002. Monitoring Ecological Impacts: Concepts and Practice in Flowing Waters. Cambridge University Press, Cambridge.

Doyle, M. W., J. M. Harbor \& E. H. Stanley, 2003a. Toward policies and decision making for dam removal. Environmental Management 31: 453-465.

Doyle, M. W., A. R. Selle, J. M. Stofleth, E. H. Stanley \& J. M. Harbor, 2003b. Predicting the depth of erosion following dam removal using a bank stability model. International Journal of Sediment Research 18: 128-134.

Doyle, M. W., E. H. Stanley \& J. M. Harbor, 2002. Geomorphic analogies for assessing probable channel response to dam removal. Journal of the American Water Resources Association 38: 567-1579.

Doyle, M. W., E. H. Stanley, D. G. Havlick, M. J. Kaiser, G. Steinbach, W. L. Graf, G. E. Galloway \& J. A. Riggsbee, 2008. Aging infrastructure and ecosystem restoration. Science 319: 286-287.

Doyle, M. W., E. H. Stanley, C. H. Orr, A. R. Selle, S. A. Sethi \& J. M. Harbor, 2005. Stream ecosystem response to small dam removal: lessons from the Heartland. Geomorphology 71: 227-244.

Gessner, M. O. \& E. Chauvet, 1993. Ergosterol-to-biomass conversion factors for aquatic hyphomycetes. Applied and Environmental Microbiology 59: 502-507.

Gore, J. A., J. R. Kelly \& J. D. Yount, 1990. Application of ecological theory to determining recovery potential of disturbed lotic ecosystems: research needs and priorities. Environmental Management 14: 755-762.

Green, R. H., 1979. Sampling Design and Statistical Methods for Environmental Biologists. Wiley, Chichester.

Hart, D. D., T. E. Johnson, K. L. Bushaw-Newton, R. J. Horwitz, A. T. Bednarek, D. F. Charles, D. A. Kreeger \& D. J. Velinsky, 2002. Dam removal: challenges and opportunities for ecological research and river restoration. Bioscience 52: 669-682.

Heinz Center, 2002. Dam removal: science and decision making. Graf, W. (Chair), The H. John Heinz III Center of Science, Economics and the Environment, Washington, DC.

Hughes, R. M., T. M. Whittier, C. M. Rohm \& D. P. Larsen, 1990. A regional framework for establishing recovery criteria. Environmental Management 14: 673-683. 
Hurlbert, S. H., 1984. Pseudoreplication and the design of ecological field experiments. Ecological Monographs 54: 187-211.

Jenny, H., S. P. Gessel \& F. T. Bingham, 1949. Comparative study of decomposition rates of organic matter in temperate and tropical regions. Soil Science 68: 419-432.

LeRoy, C. J. \& J. C. Marks, 2006. Litter quality, stream condition, and litter diversity influence decomposition rates and macroinvertebrate communities. Freshwater Biology 51: 605-617.

Malusa, J., S. T. Overby \& R. A. Parnell, 2003. Potential for travertine formation: fossil Creek, Arizona. Applied Geochemistry 18: 1081-1093.

Marks, J. C., 2007. Down go the dams. Scientific American 296: 66-71.

McCune, B. \& J. B. Grace, 2002. Analysis of Ecological Communities. MJM Software, Gleneden Beach.

Merritt, R. W. \& K. W. Cummins, 1996. An Introduction to the Aquatic Insects of North America, 3rd ed. Kendall-Hunt Publishing Company, Dubuque.

Monroe, S. A., 2002. Travertine and concrete: a geomorphological and historical study of a damsite at Fossil Creek, Arizona. MS Thesis, Northern Arizona University, Flagstaff.

Newell, S. Y., 1992. Estimating fungal biomass and productivity in decomposing litter. In Carroll, G. C. \& D. T. Wicklow (eds), The Fungal Community. Its Organization and Role in the Ecosystem. Marcel Dekker, New York: 521-561.

Niemi, G. J., P. DeVore, N. Detenbeck, D. Taylor, A. Lima, J. Pastor, J. D. Yount \& R. J. Naiman, 1990. Overview of case studies on recovery of aquatic systems from disturbance. Environmental Management 14: 571-587.

Olson, J. S., 1963. Energy storage and the balance of producers and decomposers in ecological systems. Ecology 44: 322330.

Osenberg, C. W. \& R. J. Schmitt, 1996. Before-after-controlimpact design. In Schmitt, R. J. \& C. W. Osenberg (eds), Detecting Ecological Impacts. Academic Press, San Diego: 11-16.

Palmer, M. A., E. S. Bernhardt, J. D. Allan, P. S. Lake, G. Alexander, S. Brooks, J. Carr, S. Clayton, C. N. Dahm, J. Follstad Shah, D. L. Galat, S. Gloss, P. Goodwin, D. D. Hart, B. Hassett, R. Jenkinson, G. M. Kondolf, R. Lave, J. L. Meyer, T. K. O'Donnell, L. Pagano \& E. Sudduth, 2005. Standards for ecologically successful river restoration. Journal of Applied Ecology 42: 208-217.

Petersen, R. C. \& K. W. Cummins, 1974. Leaf processing in a woodland stream. Freshwater Biology 4: 343-368.

Pinna, M., F. Sangiorgio, A. Fonnesu \& A. Basset, 2003. Spatial analysis of plant detritus processing in a Mediterranean River type: the case of the River Tirso Basin, Sardinia, Italy. Journal of Environmental Sciences 15: 227-240.

Poff, N. L. \& D. D. Hart, 2002. How dams vary and why it matters for the emerging science of dam removal. BioScience 52: 659-668.
Pollard, A. I. \& T. Reed, 2004. Benthic invertebrate assemblage change following dam removal in a Wisconsin stream. Hydrobiologia 513: 51-58.

Power, M. E., W. E. Dietrich \& J. C. Finlay, 1996. Dams and downstream aquatic biodiversity: potential food web consequences of hydrologic and geomorphic change. Environmental Management 20: 887-895.

Riggsbee, J. A., J. P. Julian, M. W. Doyle \& R. G. Wetzel, 2007. Suspended sediment, dissolved organic carbon, and dissolved nitrogen export during the dam removal process. Water Resources Research 43: W09414.

Sanders, P. F. \& J. Webster, 1980. Sporulation responses of some 'aquatic hyphomycetes' in flowing water. Transactions of the British Mycological Society 74: 601-605.

Sethi, S. A., A. R. Selle, M. W. Doyle, E. H. Stanley \& H. E. Kitchel, 2004. Response of unionid mussels to dam removal in Koshkonong Creek, Wisconsin (USA). Hydrobiologia 525: 157-165.

Smith, E. P., 2002. BACI design. In El-Shaarawi, A. H. \& W. W. Piegorsch (eds), Encyclopedia of Environmetrics, Vol. 1. Wiley, Chichester: 141-148.

Stanley, E. H. \& M. W. Doyle, 2003. Trading off: the ecological effects of dam removal. Frontiers in Ecology and the Environment 1: 15-22.

Stanley, E. H., M. A. Luebke, M. W. Doyle \& D. W. Marshall, 2002. Short-term changes in channel form and macroinvertebrate communities following low-head dam removal. Journal of the North American Benthological Society 21: 172-187.

Suberkropp, K., 2001. Fungal growth, production, and sporulation during leaf decomposition in two streams. Applied and Environmental Microbiology 67: 5063-5068.

Thorpe, J. H. \& A. P. Covich, 2001. Ecology and Classification of North American Freshwater Invertebrates, 2nd ed. Academic Press, San Diego.

Underwood, A. J., 1992. Beyond BACI: the detection of environmental impacts on populations in the real, variable world. Journal of Experimental Marine Biology and Ecology 161: 145-178.

Ward, J. V. \& J. A. Stanford, 1983. The serial discontinuity concept of river ecosystems. In Fontaine, T. D. \& S. M. Bartell (eds), Dynamics of Lotic Ecosystems. Ann Arbor Science Publications, Ann Arbor: 29-42.

Webster, J. R. \& E. F. Benfield, 1986. Vascular plant breakdown in freshwater ecosystems. Annual Review of Ecology and Systematics 17: 567-594.

Weedman, D. A., P. Sponholtz \& S. Hedwall, 2005. Fossil Creek Native Fish Restoration Project. Arizona Game and Fish Department, Phoenix.

Wiggins, G. B., 1996. Larvae of the North American Caddisfly Genera (Trichoptera), 2nd ed. University of Toronto Press, Toronto.

Yount, J. D. \& G. J. Niemi, 1990. Recovery of lotic communities and ecosystems from disturbance- a narrative review of case studies. Environmental Management 14: 547-569. 